Acta vet. scand. $1970,11,219-227$.

From the Department of Pathology, College of Veterinary Medicine, Helsinki, Finland.

\title{
GLOBULE LEUKOCYTE \\ AND MAST CELL IN BILE DUCTS OF CATTLE NATURALLY INFECTED WITH \\ LIVER FLUKES*)
}

\author{
By \\ Timo Rahko
}

The epithelium of bile ducts infected with Fasciola hepatica or Dicrocoelium dendriticum shows a pronounced glandular proliferation (Dawes \& Hughes 1964, Pantelouris 1965, Sinclair 1967, Rahko 1969a). In a previous report dealing with fascioliasis of cattle the author described the occurrence of numerous cells with eosinophilic intracytoplasmic globules in the hyperplastic epithelium of main bile ducts (Rahko 1969a). The globules stained metachromatically like the granules in tissue mast cells, which occurred in increased numbers in the walls of the bile ducts and in the liver parenchyma. The available literature concerning the liver fluke disease of cattle presents no information on such intraepithelial cells (Rahko 1968). In recently published investigations, however, similar intraepithelial cells in the bile ducts of sheep with experimental fascioliasis are described as globule leukocytes (Miller et al. 1968, Murray et al. 1968).

The origin and function of the globule leukocyte has not yet been definitely established (Murray et al.). During parasitic infections the cell occurs in large numbers within the epithelium of mucous membranes in the alimentary, urinary and respiratory tracts of various mammals and the fowl (Kirkman 1950, Kent 1952, Sommerville 1956, Whur \& Johnston 1967, Miller et al.,

*) Supported by a grant from National Research Council for Medical Sciences. 
Murray et al.). The globule leukocyte is described as displaying large eosinophilic intracytoplasmic globules, which are spherical and usually occur between ten and twenty in number. The globules stain metachromatically with toluidine blue and show a strong reaction with Alcian blue and amidoblack. The cell usually presents an eccentric nucleus with a chromatin pattern similar to that of the lymphocyte or plasma cell (Kirkman, Kent, Whur \& Johnston, Miller et al., Murray et al.).

The purpose of the present histological and histochemical investigation is to show that the unknown cell type in bile ducts of cattle with fascioliasis previously described by the author may be considered a globule leukocyte. The relationship of this cell to the subepithelial mast cell and the appearance of these cells in dicrocoeliasis is also investigated.

\section{MATERIAL AND METHODS}

The material was collected from cattle naturally infected with Fasciola hepatica or Dicrocoelium dendriticum. Uninfected livers were used as controls. Tissues were taken from various sections of the intrahepatic bile ducts and ductus choledochus. The sections were fixed in $10 \%$ neutral formalin or Bouin's fluid, embedded in paraffin and cut at 4 or $5 \mu$. Paraffin sections were stained according to standard methods (manuals of Roulet 1948 and the Armed Forces Institute of Pathology 1960) with haematoxylin and eosin (HE), van Gieson, Ladewig-Mallory, periodic acid-Schiff (PAS) with and without preceding diastase digestion, Best's carmine, Mayer's mucicarmine, Unna's methyl-green-pyronin, methyl-violet for amyloid, Hueck's stain for iron, von Kossa's stain for calcium and the frozen sections for demonstration of fat with Sudan IV or Oil red 0. Selected paraffin sections were stained with amidoblack (Whur \& Johnston 1967), toluidine blue (thiazine dye) in an $0.5 \%$ aqueous solution at $\mathrm{pH} 4.0$ (McIlvaine's citric acid disodium phosphate buffer) with a staining time of 45 sec., and in an $0.1 \%$ aqueous solution at $\mathrm{pH} 0.3$ (toluidine blue was diluted in $0.7 \mathrm{~N}-\mathrm{HCL}$ ) for $10 \mathrm{~min}$. followed by rinsing in $0.7 \mathrm{~N}-\mathrm{HCL}$ for $10 \mathrm{~min}$. (Enerbäck 1966b), Alcian blue (copper phthalocyanine dye) in an $0.1 \%$ aqueous solution at $\mathrm{pH}$ 0.3 with a staining time of 10 min., counterstained with $0.5 \%$ safranin at $\mathrm{pH} 1$ (the dye was diluted in $0.125 \mathrm{~N}-\mathrm{HCL}$ ) for 30 sec. (Enerbäck 1966b). 


\section{RESULTS}

Numerous globule leukocytes occurred in the hyperplastic epithelium of the main bile ducts (Fig. 1). The amount, however, varied in the investigated livers, and no relationship seemed to exist between the amount of globule leukocytes and the number of living parasites. The largest number of cells occurred in the ductus choledochus, but only few cells were found in substancially altered and eroded sections of the main intrahepatic bile ducts. In livers with fascioliasis the cells were rarely observed in small perilobular bile ducts as was frequently the case in livers with dicrocoeliasis (Fig. 2). No other divergencies concerning the globule leukocytes were observed in livers infected with Fasciola or, on the other hand, Dicrocoelium. Uninfected control livers showed only a few globule leukocytes.

Globule leukocytes were distinctly demonstrated with haematoxylin-eosin or the Ladewig-Mallory staining method owing to the acidophilic properties of the intracytoplasmic globules and, on the other hand, their occurrence in the epithelial tissues (Fig. 3 ). The globules were well preserved with both formalin and Bouin's fixatives. The cells presented an eccentric nucleus, which frequently had a pycnotic appearance or was similar to the nucleus of the lymphocyte or the plasma cell. The cytoplasm was filled with numerous fairly large globules, which were spherical and usually of similar size. Some cells, however, showed one or several larger globules (Fig. 4). It was not possible to demonstrate any matrix of cytoplasm between the globules with the staining methods employed.

The cytochemical properties of globule leukocytes are demonstrated in Table 1. The globules of most cells showed violet metachromasia with toluidine blue at $\mathrm{pH} 4$ and some stained from deep blue to almost colourless. The intensity of reactions at $\mathrm{pH} 0.3$ was much less. With Alcian blue-safranin the globules bound Alcian blue to a varying extent. Many globules stained irregularly with a deeper blue zone in their periphery while some globules were colourless (Fig. 5).

Mast cells occurred in large numbers in the subepithelial tissues of the main bile ducts and were usually arranged around blood capillaries. The observed cells were rounded in the loose tissues but more or less spindle-shaped in the dense fibrous areas. The cells presented numerous small intracytoplasmic gran- 

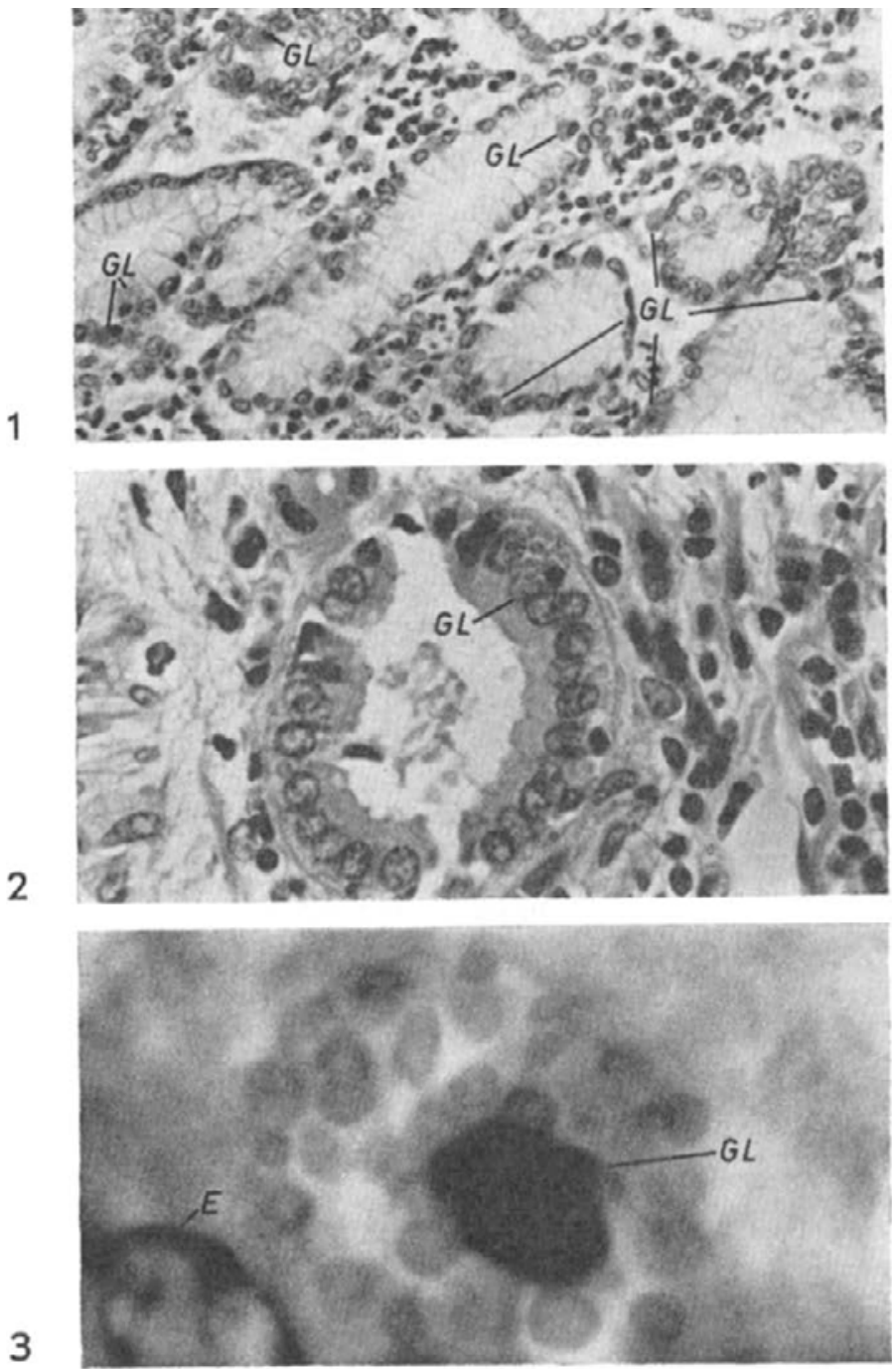

F i g u r e 1. Liver with fascioliasis. Several intraepithelial globule leukocytes (GL). He $\times 240$.

F i g u r 2. Liver with dicrocoeliasis. Small perilobular bile duct with globule leukocyte (GL). HE $\times 540$.

F i g u r e 3. Liver with fascioliasis. Globule leukocyte (GL) showing chromatin-rich nucleus and numerous acidophilic intracytoplasmic globules. E: nucleus of epithelial cell. $\mathrm{HE} \times 3200$. 
T a b l e 1. Cytochemical properties of globule leukocytes and mast cells in bile ducts of cattle infected with liver flukes.

\begin{tabular}{|c|c|c|}
\hline & Globule leukocyte & Mast cell \\
\hline Haematoxylin and eosin & $\mathbf{r}$ & $\mathbf{b} / \mathbf{r}$ \\
\hline Ladewig-Mallory & $\mathbf{r}$ & $\mathbf{b} / \mathbf{r}$ \\
\hline Van Gieson & $\mathbf{y}$ & $\mathbf{y}$ \\
\hline Periodic acid-Schiff (PAS) & + & + \\
\hline PAS with diastase digestion & + & + \\
\hline Best's carmine & + & + \\
\hline Mayer's mucicarmine & - & $+1-$ \\
\hline Alcian blue-safranin & $\mathbf{b}$ & $\mathbf{b} / \mathbf{r}$ \\
\hline Toluidine blue metachromasia, pH 4.0 & $+1-$ & + \\
\hline Toluidine blue metachromasia, pH 0.3 & - & $+1-$ \\
\hline Methyl-violet metachromasia & - & - \\
\hline Methyl-green-pyronin & - & + \\
\hline Amidoblack & + & - \\
\hline Sudan IV and Oil red 0 & - & - \\
\hline Hueck's iron-stain & - & - \\
\hline von Kossa's calcium-stain & - & - \\
\hline
\end{tabular}

+ positive reaction,

- no reaction,

b blue,

r red,

y yellow.

ules, which frequently covered the nucleus. The cells were distinctly demonstrated with toluidine blue or Alcian blue, but with many other staining methods they were easily overlooked (Fig. 6). The cells presented variations in their histochemical reactions (Table 1) and in the amount of granules. No divergencies were observed in the appearance of mast cells between fascioliasis and dicrocoeliasis.

In addition to the intraepithelial globule leukocytes and the subepithelial mast cells certain intraepithelial cells occurred much resembling ordinary mast cells. Some of these cells, however, presented one or several larger globules similar to those of the globule leukocyte.

\section{DISCUSSION}

Detailed information on the morphology and histochemistry of globule leukocyte in various mucous membranes of parasitized animals is available in several publications (Kirkman 1950, Kent 1952, Whur \& Johnston 1967, Miller et al. 1968, Murray et al. 

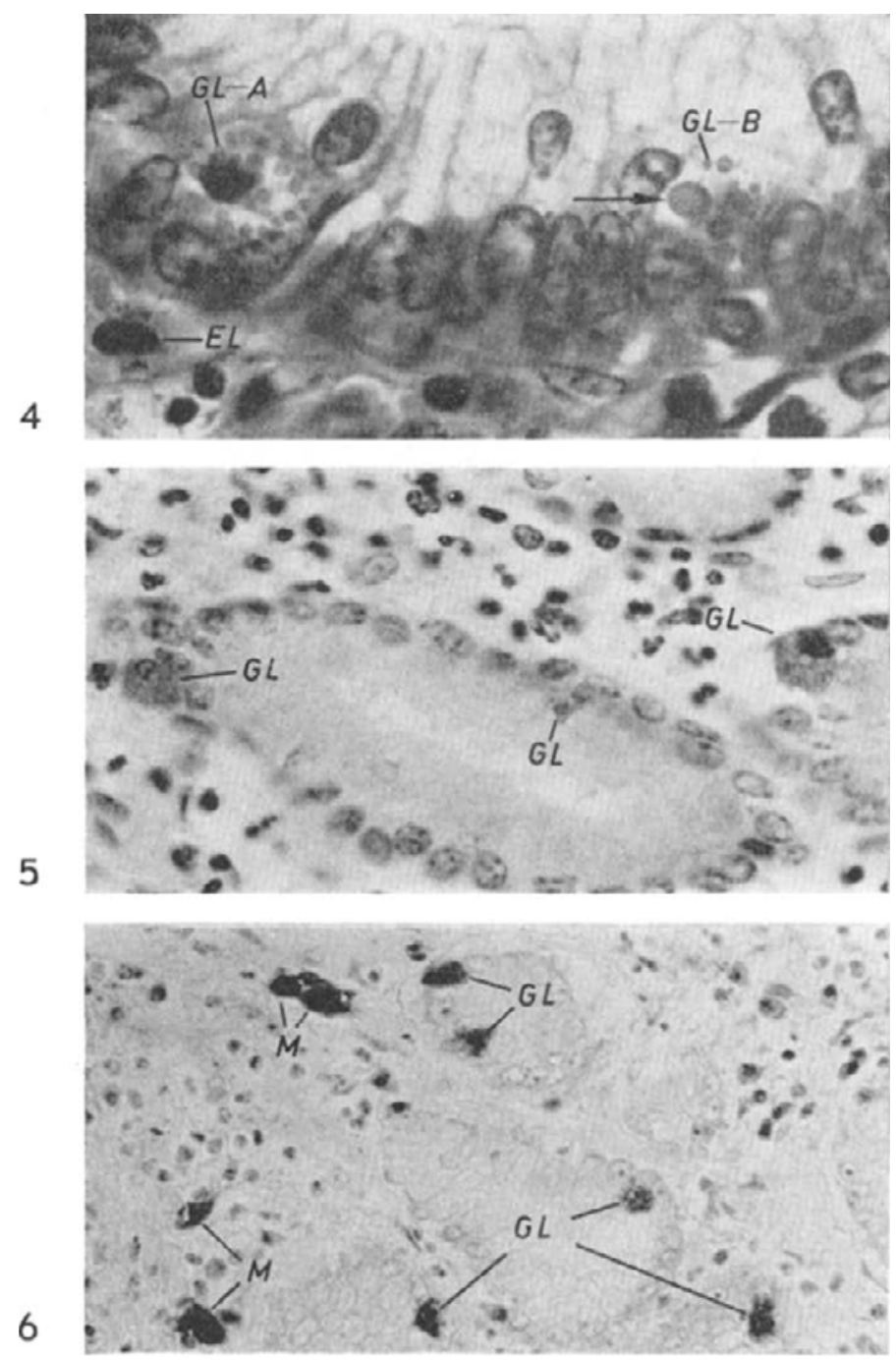

Fig u r e 4. Liver with fascioliasis. Globule leukocyte with globules of usual size (GL-A) and with several big globules (GL-B). Largest globule marked with arrow. Note the morphological differences between eosinophilic leukocyte (EL) and globule leukocyte. HE $\times 1125$.

Figure 5. Liver with fascioliasis. Globules of globule leukocyte (GL) binding Alcian blue irregularly, being rimmed by darker zone. Alcian blue-haematoxylin $\times 540$.

F i g u r e 6. Liver with fascioliasis. Subepithelial mast cells (M) and intraepithelial globule leukocytes (GL) showing differences in the metachromasia. Note the pronounced contrast of mast cells. Toluidine blue at $\mathrm{pH} 4.0 \times 320$. 
1968). These publications present a relevant basis for the identification of the globule leukocyte. According to the above mentioned characteristics the unknown cell type previously described by the author (Rahko 1969a) in bile ducts of cattle with spontaneous fascioliasis may be defined as a globule leukocyte.

The present investigation revealed that no difference exists in the structure and histochemical reactions of bovine globule leukocyte between fascioliasis and dicrocoeliasis. Preliminary studies on globule leukocytes of cattle and sheep with fascioliasis showed similar results (Rahko 1969b). Thus the author suggests that the globule leukocytes found in the biliary tract of cattle and sheep suffering from parasitic cholangitis are to be considered an analogous type of cell and that they possibly may be identical. However, differences seem to occur in the distribution of globule leukocytes between fascioliasis and dicrocoeliasis. In dicrocoeliasis even small perilobular bile ducts frequently showed globule leukocytes, which was not the case in fascioliasis.

The histochemical reactions of the mast cells varied somewhat. With toluidine blue at $\mathrm{pH} 0.3$ mast cells remained colourless or stained weakly blue-violet while presenting intense metachromasia at pH 4.0. Most cells bound Alcian blue strongly even when counterstained with safranin, but a few cells also presented red granules. Because the stabile staining properties of mast cells depend on the technical procedures (Enerbäck $1966 \mathrm{a}, \mathrm{b}$ ), the variabilities in the histochemical reactions of mast cells as noted by the author do not necessarily point to the existence of different types of cells. Variations in the reaction with Alcian blue-safranin, however, may be indicative of differences in the degree of sulphation (Enerbäck $1966 \mathrm{~b}$, Murray et al.).

The histogenesis of globule leukocytes from the immunoglobulin-producing cells as suggested by many authors (Kirkman, Kent, Whur \& Johnston) is refuted in the most recent investigations pointing to their derivation from the subepithelial mast cell (Miller et al., Murray et al., Jarrett et al. 1968). The present investigations show that the mast cells and globule leukocytes display certain similarities in their histochemical reactions. It was demonstrated that both cell types contain a sulphated acid mucopolysaccharide by their specific reactivity to thiazine and copper phthalocyanine dyes. Furthermore, an increased number of mast cells and globule leukocytes was established in the walls of bile ducts. These findings are supported 
by recent investigations on the appearance of intestinal mast cells and globule leukocytes (Wells 1962, Jarrett et al., Miller et al., Murray et al.).

\section{REFERENCES}

Armed Forces Institute of Pathology: Manual of Histologic and Special Staining Technics. 2nd Ed. McGraw-Hill, New York 1960.

Dawes, B. \& D. L. Hughes: Fascioliasis. The invasive stages of Fasciola hepatica in mammalian hosts. Advanc. Parasitol. 1964, 2, 97168.

Enerbäck, L.: Mast cells in rat gastrointestinal mucosa. I. Effects of fixation. Acta path. microbiol. scand. 1966 a, 66, 289-302.

Enerbäck, L.: Mast cells in rat gastrointestinal mucosa. II. Dyebinding and metachromatic properties. Acta path. microbiol. scand. $1966 \mathrm{~b}, 66,303-312$.

Jarrett, W. F. H., E. E. E. Jarrett, H. R. P. Miller \& G. M. Urquhart: Quantitative studies on the mechanism of self cure in Nippostrongylus brasiliensis infections. In Reaction of Host to Parasitism, ed. E. L. Soulsby, Academic Press, Inc., New York 1968.

Kent, J. F.: The origin, fate and cytochemistry of the globule leukocyte of the sheep. Anat. Rec. 1952, 112, 91-115.

Kirkman, H.: A comparative morphological and cytochemical study of globule leucocytes (Schollenleukocyten) of the urinary tract and possible related cells. Amer. J. Anat. 1950, 86, 91-127.

Miller, H. R. P., M. Murray \& W. F. H. Jarrett: Globule leukocytes and mast cells. In Reaction of Host to Parasitism, ed. E. L. Soulsby, Academic Press, Inc., New York 1968.

Murray, M., H. R. P. Miller \& W. F. H. Jarrett: The globule leukocyte and its derivation from the subepithelial mast cell. Lab. Invest. 1968, 19, $222-234$.

Pantelouris, E. M.: The Common Liver Fluke. Pergamon Press, Oxford 1965.

Rahko, T.: The pathology of natural Fasciola hepatica infection in cattle. Path. Vet. 1969a, 6, 244-256.

Rahko, T.: Mastceller og ,globule leukocytes“ i gallegangene hos storfe og småfe ved fascioliasis. (Mast cells and "globule leukocytes" in bile ducts of cattle and sheep with fascioliasis). Medlemsbl. norske Vet.-Foren. 1969, 21, 377-381.

Roulet, F.: Methoden der Pathologischen Histologie. (Methods of pathohistology). Springer, Wien 1948.

Sinclair, K. B.: Pathogenesis of Fasciola and other liver flukes. Helminth. Abstr. 1967, 36, 115-134.

Sommerville, R. J.: The histology of the ovine abomasum and relation of the globule leucocyte to nematode infections. Aust. vet. J. 1956, 32, 237-240. 
Wells, P. D.: Mast cell, eosinophil and histamine levels in Nippostrongylus brasiliensis infected rats. Exp. Parasit. 1962, 12, 82-101.

Whur, P. \& H. S. Johnston: Ultrastructure of globule leukocytes in immune rats infected with Nippostrongylus brasiliensis and their possible relationship to the Russell body cell. J. Path. Bact. 1967, 93, 81-85.

\section{SUMMARY}

In a previous report dealing with the pathology of bovine fascioliasis the author described an unknown cell type in the epithelium of bile ducts. The histological and histochemical investigations published in this paper suggest that the cell may be considered a globule leukocyte. Globule leukocytes are rare in uninfected livers but are occurring in abundance in main bile ducts of cattle with spontaneous fascioliasis and also in small perilobular ducts in dicrocoeliasis. Liver fluke infection causes an increase in the population of subepithelial mast cells. Mast cell and globule leukocyte present similarities in their cytochemical properties. However, at low $\mathrm{pH}$ toluidine blue shows a stronger but Alcian blue a weaker affinity for mast cells than for globule leukocytes.

\section{SAMMANFATTNING}

„Globule“ leukocyter och mastceller $i$ gallgångarna hos nöt spontant infekterade med leverflundra.

I en tidigare publikation om patologin hos nöt med fascioliasis har författaren beskrivit en okänd celltyp i gallgångsepitelet. I denna artikel publicerade histologiska och histokemiska undersökningar visar, att denna cell bör uppfattas representera en cell av typen ,globule“ leukocyt. „Globule“ leukocyt förekommer sparsamt i icke infekterade levrar, men rikligt $i$ de större gallgångsförgreningarna hos nöt med spontan fascioliasis och dessutom i smärre perilobulära gallgångar hos nöt med dicrocoeliasis. Infektion med leverflundra orsakar en ökning av populationen med avseende på subepiteliala mastceller. Mastceller och "globule“ leukocyter presentera analoga cytokemiska egenskaper. Toluidin blått visar emellertid vid låg $\mathrm{pH}$ en starkare, däremot Alcian blått en svagare affinität för mastceller än för ,globule" leukocyter. 